\title{
THE REVIVAL OF SKIDMORE v. SWIFT: JUDICIAL DEFERENCE TO AGENCY INTERPRETATIONS AFTER EEOC v. ARAMCO
}

\author{
JAMIE A. YAVELBERG
}

\section{INTRODUCTION AND HISTORICAI BACKGROUND}

Although Skidmore v. Swift \& Co. ${ }^{1}$ was decided almost fifty years ago, it remams the authoritative statement on the role of interpretive rules in administrative law. As the courts increasingly defer to agency imterpretations of statutes, Skidmore becomes even more meaningful in the scope of review area. Skidmore established a doctrine of cautious deference with regard to agency interpretations. In contrast, Chevron U.S.A. Inc. v. National Resources Defense Council, Inc. ${ }^{2}$ mandated deference to any reasonable agency interpretation. As agencies nay exercise a variety of powers, courts evaluating agency rules have available to them both the Skidmore and Chevron deference principles. The two principles are distinct, and properly apply to discrete situations. The courts, however, liave intertwined the Skidmore and the Chevron principles, applying the Chevron doctrine of extreme deference to Skidmore situations. This has led to the mistaken assumption that Chevron has completely eviscerated the significance of Skidmore. In order to combat the swallowing of the Skidmore decision by the Chevron tiger, the courts inust recognize and preserve the fundamental differences between the Skidmore and the Chevron deference principles. The Supreme Court did just that last year in Equal Employment Opportunity Commission v. Arabian American Oil Co. $\left(\right.$ Aramco) ${ }^{3}$

The intricate web of administrative agencies in the federal system is often referred to as the "Fourth Branch" of govern-

\footnotetext{
1. 323 U.S. 134 (1944).

2. 467 U.S. 837 (1984).

3. 111 S. Ct. 1227 (1991).
} 
ment. ${ }^{4}$ Agencies not only adjudicate claims, but also make rules and regulations that reflect their interpretations of congressional statutes. As the interpretive role of agencies has grown, the courts have grappled with the question of what level of deference to give agency opimions. ${ }^{5}$

The courts' difficulty in arriving at the proper standard of review is attributable to the agency's overlapping functions, as legislature, executive, and judiciary. An agency's regulations and guidelines resemble congressional legislation; its enforcement and prosecutorial roles are examples of executive powers; and its interpretation of congressional statutes is an exercise of a judicial function. ${ }^{6}$ When evaluating agency action, a court must evaluate the agency action itself; but ultimately a court's review of the agency's judgment will depend on which governmental power the agency was exercising when it acted.

Before determining the appropriate level of judicial deference to agency action, it is important to note the fundamental distinction between two types of agency rules: legislative and interpretive. ${ }^{7}$ Legislative rules derive their force from a congressional

4. Peter L. Strauss, The Place of Agencies in Government: Separation of Powers and the Fourth Branch, 84 COLUM. L. REv. 573 (1984).

5. See Colin S. Diver, Statutory Interpretation in the Administrative State, 133 U. PA. L. REV. 549, 564-67 (1985) (noting the difficulty of defining the term "deference").

6. There is necessarily a tension between courts and agencies when agencies assume an interpretive role. Any sort of deference by a court to an administrative agency's interpretation of a congressional act could be seen as an abdication of the judicial function. See Cynthia R. Farina, Statutory Interpretation and the Balance of Power in the Administrative State, 89 CoLum. L. REv. 452,452 n.4 (1989).

"It is emphatically the province and duty of the judicial department to say what the law is." Marbury v. Madison, 5 U.S. (1 Cranch) 137, 177 (1803). Justice Marshall based much of his reasoning in Marbury on Alexander Hamilton's Federalist Paper No. 78: "The interpretation of the laws is the proper and peculiar province of the courts." THE FEDERALIST No. 78, at 467 (Alexander Hamilton) (Clinton Rossiter ed., 1961).

From the inception of our democracy, the conflict regarding the structural role of the judiciary was bound to collide with the establishment of executive agencies. One of the most prominent cases touching on this conflict is Marbury itself.

7. See 2 KENNETH C. DAVIS, ADMinISTRATIVE LAw TREATISE $\$ \S 7: 8-7: 12$ (2d ed. 1979). Rules can also be characterized as legislative and nonlegislative. Nonlegislative rules make up the body of agency action that lacks a congressional grant of power and include interpretive rules and policy statements. Professor Robert Anthony has distinguished these two types of nonlegislative rules. See Robert A. Anthony, Interpretive Rules, Policy Statements, Guidances, Manuals, and the Like-Should Federal Agencies Use Them to Bind the Public?, 41 DUKE L.J. 1311, 1323-27 (1992). This Note, however, uses Davis's terminology and refers exclusively to legislative rules and interpretive rules, with "interpretive rules" signifying nonlegislative agency action, including policy statements. 
grant of power to agencies to make law through rulemaking. The congressional grant can be broad, general, vague, or uncertain. ${ }^{8}$ To be valid, a legislative rule must be enacted pursuant to the procedures established in the Administrative Procedure Act (APA). ${ }^{9}$ Once enacted, a legislative rule is binding on the courts and has the same effect as a congressional statute. ${ }^{10}$

On the other hand, agencies can issue interpretive rules without exercising a congressional grant of rulemaking power. Interpretive rules can be issued in a variety of forms, mcluding: manuals, pohicy statements, staff instructions, opinion letters, audits, correspondence, informal advice guidelines, press releases, testimony before Congress, internal memoranda, speeches, and explanatory statements in the Federal Register. ${ }^{11}$ An agency can issue an interpretive rule without adhering to the formal rulemaking procedures or informal notice-and-comment procedures of the APA. ${ }^{12}$ An interpretive rule is not binding on the courts, ${ }^{13}$ courts may freely substitute their judgment for that of the agency in determining how a statute or regulation is to be implemented. ${ }^{14}$ An interpretive rule is "merely advisory," clarifying or expressing the agency's understanding of a statute. ${ }^{16}$ In reviewing an interpretive

8. DAVIS, supra note $7, \S 7: 10$.

9. See 5 U.S.C. \& 553 (1988); Samaritan Health Serv. v. Bowen, 811 F.2d 1524, 1529 (D.C. Cir. 1987).

10. Batterton v. Francis, 432 U.S. 416, 425 n.9 (1977); National Latino Media Coalition v. FCC, 816 F.2d 785, 788 (D.C. Cir. 1987).

11. Robert A. Anthony, Which Agency Interpretations Should Bind Citizens and the Courts?, 7 YALE J. ON REG. 1, 2 (1990).

12. Flagstaff Medical Ctr. v. Sullivan, 773 F. Supp. 1325, 1350 (D. Ariz. 1991), aff'd in part, rev'd in part, 962 F.2d 879 (9th Cir. 1992); see 5 U.S.C. $\S$ 553(c) (1988); see also Northern Ill. Gas Co. v. United States, 833 F.2d 1582, 1583 (Fed. Cir. 1987) (IRS revenue ruling was an interpretive mling and therefore not subject to the APA); Westcott v. Department of Agric., 765 F.2d 121, 122 (8th Cir. 1985) (Department of Agriculture handbook was interpretive only and therefore not subject to APA notice-and-comment requirements).

13. However, interpretive mles may be binding on the agency itself. See, e.g., Morton v. Ruiz, 415 U.S. 199, 235 (1974) ("Where the rights of individuals are affected, it is incumbent upon agencies to follow their own procedures."); Prince v. Sullivan, 933 F.2d 598, 602 (7th Cir. 1991) ("Social Security rulings are 'binding on all components of the Administration. [They] represent precedent final opinions and orders and statements of policy and interpretations that have been adopted by the Administration." (quoting 20 C.F.R. $\S 422.406(b)(1)(1990))$.

14. See, e.g., Batterton, 432 U.S. at 425 n.9 (court is not required to give effect to an interpretive regulation); Sciarotta v. Bowen, 735 F. Supp. 148, 151 (D.N.J. 1989) (reviewing court may use its own judgment as to what the authorizing statute may require).

15. Sciarotta, 735 F. Supp. at 151.

16. See National Latino Media Coalition v. FCC, 816 F.2d 785, 788 (D.C. Cir. 1987); 
rule, a court may weigh the rule into its decision on how to interpret the statute, depending on the rule's persuasiveness. ${ }^{17}$

Although some courts have characterized the line dividing legislative from interpretive rules as "hazy," "fuzzy,"19 and "enshrouded in considerable smog," the difference between the two types of rules is really quite clear. ${ }^{21}$ A legislative rule is grounded in a congressional grant of power and enacted pursuant to APA procedures; an interpretive rule is not. ${ }^{22}$ Courts that have had difficulty with the distinction have focused on a rule's impact instead of its origin. ${ }^{23} \mathrm{~A}$ rule is legislative if it creates new rights, produces significant effects on private interests, or imposes obligations on the public, because only rules liaving tlie force of law supported by a congressional grant of power could have these effects. ${ }^{24}$ But although a rule having these substantive and inti-

Flagstaff, 773 F. Supp. at 1343; see infra notes $181-82$ and decisions cited therein.

17. See, e.g., General Elec. Co. v. Gilbert, 429 U.S. 125, 141-42 (1976); Skidmore v. Swift \& Co., 323 U.S. 134, 140 (1944). As one court has noted, "[a]t bottom, the true measure of the weight to be accorded to the [agency's] view inevitably depends upon the persuasive force of the interpretation, given the totality of the attendant circumstances." Bank of New York v. Hoyt, 617 F. Supp. 1304, 1314 (D.R.I. 1985) (citing Skidmore, 323 U.S. at 140 ).

18. Klingler v. Yamaha Motor Corp., 738 F. Supp. 898, 903 (E.D. Pa. 1990).

19. Pacific Gas \& Elec. Co. v. Federal Power Comm'n, 506 F.2d 33, 38 (D.C. Cir. 1974).

20. Noel v. Chapman, 508 F.2d 1023, 1030 (2d Cir.) (referring to definition of "general statement of policy"), cert. denied, 423 U.S. 824 (1975).

21. See Anthony, supra note 7, at 1321.

22. See American Fed'n of Gov't Einployees v. United States, 622 F. Supp. 1109, 1116 (N.D. Ga. 1984), aff d, 780 F.2d 720 (11th Cir. 1986); Ainerican Meat Inst. v. Bergland, 459 F. Supp. 1308, 1314 (D.D.C. 1978).

23. See, e.g., General Motors Corp. v. Ruckelshaus, 742 F.2d 1561, 1565-66 (D.C. Cir. 1984), cert. denied, 471 U.S. 1074 (1985); Flagstaff Medical Ctr. v. Sullivan, 773 F. Supp. 1325, 1351 (D. Ariz. 1991), aff'd in part, rev'd in part, 962 F.2d 879 (9th Cir. 1992); Klingler v. Yamaha Motor Corp., 738 F. Supp. 898, 903 (E.D. Pa. 1990); see also Anthony, supra note 7, at 1327 (msisting that origin, rather than effect, of a rule determines whether it is legislative). Even though the substantial inpact test has been repudiated by the courts, some courts beheve impact remains relevant to classifying a rule as legislative or interpretive. See, e.g., Credit Union Nat'l Ass'n v. National Credit Union Admin. Bd., 573 F. Supp. 586, 591 (D.D.C. 1983). Indeed, if an interpretive rule or policy statement has a substantial impact, some judges and scholars advocate using the notice-and-comment process. Pliarmaceutical Mfrs. Ass'n v. Fincli, 307 F. Supp. 858, 863-64 (D. Del. 1970); Antliony, supra note 7, at 1327, 1355; see also DAVIS, supra note $7, \S$ 7:17 (analyzing cases holding that rules with a substantial impact require the notice-andcomment procedure, but also pointing out that sucl rules are not thereby converted into "legislative rules").

24. . See Chrysler Corp. v. Brown, 441 U.S. 281, 301-03 (1979) (quoting Morton v. Ruiz, 415 U.S. 199, 232, 235, 236 (1974)). 
mate effects should be legislative, agencies sometimes try to achieve the same ends through an interpretive rule or a policy statement, which can be promulgated without the comphicated and confrontational procedures of legislative rulemaking. ${ }^{25}$ Courts using impact as a guide would understandably find it difficult to distinguish interpretive rules, which are legislative in nature, from properly promulgated legislative rules. It is an entirely different debate whether or not an agency should issue interpretive rules that bind the public. ${ }^{26}$

In determining the appropriate level of judicial deference to agency action, it is essential to examine the history of judicial deference to agency rulemaking. The primciples of judicial deference can be traced back to the early decisions of the Supreme Court. ${ }^{27}$ More than a century later, the growth of administrative agencies during the New Deal compelled the Court to fit its review of agency action into its general framework of judicial review. Since then, several of the Court's decisions established principles of judicial deference to apply to agency imterpretations. ${ }^{28}$

25. The rules and policies in the following cases were established by agency officials and were not promulgated pursuant to notice-and-comment: Rust v. Sullivan, $111 \mathrm{~S}$. Ct. 1759, 1764 (1991) (gag rule prohibiting discussion of abortion by health care officials receiving federal financial assistance); Wisconsin Dep't of Health \& Human Servs. v. Bowen, 797 F.2d 391, 397 (7th Cir. 1986) (rule strictly interpreting utilization provisions used to disallow Medicaid reimbursements), cert. granted, 479 U.S. 1053 (1987), and cert. dismissed, 485 U.S. 1017 (1988); Rivera v. Becerra, 714 F.2d 887, 891 (9th Cir. 1983) (pension benefits offset by unemployment benefits), cert. denied, 465 U.S. 1099 (1984); American Medical Assoc. v. Heckler, 606 F. Supp. 1422, 1440 (S.D. Ind. 1985) (rule freezing amount providers are allowed to charge Medicare beneficiaries); Linoz v. Heckler, 598 F. Supp. 486, 490 (D. Haw. 1984) (derrial of Medicare coverage for ambulance service to distant hospital), rev'd, 800 F.2d 871 (9th Cir. 1986) (striking down substantive rule because it was not promulgated in accordance with notice-and-comment procedures); see also Wilcox v. Ives, 864 F.2d 915, 926 (1st Cir. 1988) ("Under the guise of interpretation, the Secretary has effected a fundamental change in the purpose of the statute."). For a more complete analysis of the interpretive rule question in Rust, see Walter Dellinger, Gag Me with a Rule: Bush and Abortion Counseling, NEW REPUBLIC, Jan. 6, 1992, at 14.

26. See Anthony, supra note 7 , at 1315.

27. See, e.g., United States v. Vowell \& M'Lean, 9 U.S. (5 Cranch) 368, 372 (1808) (had it been necessary to do so, the Court would have respected the consistent construc'tion of the Treasury Department on the issue of bondholder's duties, an area in which the treasury had experience); see also Farina, supra note 6 , at 452 n.4 (noting that the underlying question of Marbury v. Madison involved an opportunity for judicial deference to an administrative interpretation of the Judiciary Act of 1789).

28. See Skidmore v. Swift \& Co., 323 U.S. 134, 139-40 (1944); Batterton v. Francis, 432 U.S. 416, 425 (1977); Chevron U.S.A. Inc. v. Natural Resources Defense Council, Inc., 467 U.S. $837,842-43$ (1984). 
In litigation involving an agency when the meaning of statutory language is in dispute, the agency charged with administering that statute frequently asks the court to defer to the agency's interpretation of the statute. The agency may offer a variety of documents in support of its position, including many types of legislative or interpretive rules. Confronted with this myriad of agency action, a court must determine the appropriate level of judicial deference to give the agency's interpretation.

In 1944, the Supreme Court decision of Skidmore v. Swift \& $\mathrm{Co}^{29}$ established the proper role of an interpretive rule in the judicial decisionmaking process. Skidmore's deference principle requires courts to evaluate the persuasive force of such a rule, and to give that rule weight in its decisionmaking process depending on that force.

In Skidmore, the Supreme Court provided general principles for courts to use when dealing with agency interpretations. The Court explained that although the agency's opinion was valued, the agency's interpretation of the statute at issue nonetheless could not effectively bind the courts. ${ }^{30}$ It thus undertook its own evaluation of the meaming of the terms in the statute. Yet the Court afforded the agency's recommendations some consideration: it held that the level of judicial deference to an agency opinion depends on the persuasiveness of the agency's position as measured by the thoroughness of its investigation in making the ruling, the vahidity of its reasoning, and the consistency of the present agency position with earher rulings. ${ }^{31}$ Although it offered guidance to lower courts regarding the proper relationship between a reviewing court and an agency interpretation, Skidmore did not settle the deference debate. $^{32}$

29. 323 U.S. 134 (1944).

30. Id. at 139-40; see infra notes 58-60 and accompanying text.

31. Skidmore, 323 U.S. at 140.

32. Also in 1944, the Court developed a separate set of deference principles to apply to agency adjudications. See NLRB v. Hearst Publications, 322 U.S. 111, 130 (1944). When evaluating agency adjudications, factual determinations would be left to the agency whereas legal ones were left exclusively to the courts. See id. (explaining that whether newsboys are "employees" was a question of fact left to the agency). However, this test has proved to be problematic as questions frequently arise that mix fact and law, and it has become increasingly difficult to apply the test consistently. See, e.g., Connecticut State Medical Soc'y v. Connecticut Bd. of Examiners in Podiatry, 546 A.2d 830 (Conn. 1988) (holding that what constitutes the foot in the human body is a question of law); see also 2 Charles H. KOCH, JR., ADMINISTRATIVE LAW \& PRACTICE 116-17 (1st 
With the regulatory boom of the 1970s, the deference debate moved to the forefront of the Court's docket. Although the general principles of deference established in earlier decisions remained viable, the question for the Court was no longer "should courts defer?" but rather "how much deference should courts give?" Two competing lines of cases emerged from the debate: cases that followed the checks and balances approach, and cases that followed the supervisory approach. ${ }^{33}$ Under the checks and balances approach, a court afforded great deference to a reasonable agency interpretation of a statute. ${ }^{34}$ A court reviewed an agency's decision as it would congressional legislation and often accepted the agency's interpretation as controlling. The strength of the agency's opimion was bolstered by the agency's status as a co-equal "fourth branch" of government. In contrast, under the supervisory approach, a court weighed the persuasive value of an agency's opinion in inaking its own evaluation of the ineaning of the statute; and the court was always free to substitute its judgment for that of the agency. ${ }^{35}$ Here, the persuasive power of the agency rested on considerations such as its expertise, experience, and consistency in applying the interpretation. These conflicting cases created confusion and ambiguity in the law governing judicial deference to agency interpretations for the next decade. ${ }^{36}$

ed. Supp. 1990) (discussing the use of a fact/law distinction in judicial review).

33. Kenneth W. Starr, Judicial Review in the Post-Chevron Era, 3 YALE J. ON REg. 283, 300-07 (1986). Other commentators, such as Cynthia Farina, refer to these approaches respectively as the "deferential model" and the "independent judgment model." See Farina, supra note 6 , at $453-54$.

34. See, e.g., Ehlert v. United States, 402 U.S. 99 (1971) (holding that a court is obligated to regard as controlling a reasonable, consistently apphied administrative interpretation); Red Lion Broadcasting Co. v. FCC, 395 U.S. 367 (1969) (holding that an agency mterpretation should be followed unless there are compeiling indications that it is wrong).

35. See, e.g., NLRB v. Bell Aerospace Co., 416 U.S. 267, 289 (1974) (court conducted its own evaluation of legislative history of Taft-Hartley Act rather than accept agency interpretation where agency interpretation was inconsistent with its earlier pronouncements); Office Enployees Int'I Union v. NLRB, 353 U.S. 313, 320 (1957) (refusing to defer to agency interpretation where agency would limit its own jurisdiction); Davies Warehouse Co. v. Bowles, 321 U.S. 144, 156 (1944) (agency view does not outweigh court's own interpretation of the statute); see also Morton v. Ruiz, 415 U.S. 199, 232 (1974) (court will not defer to agency's ad hoc determination of ehgibility for benefits).

36. As Judge Friendly has commented:

We think that it is time to recognize ... that there are two lines of Supreme Court decisions on this subject which are analytically in conflict, with the result that a court of appeals must choose the one it deems more appropriate for the case at hand. Leading cases support[ ] the view that great deference 
In 1984, in Chevron U.S.A. Inc. v. Natural Resources Defense Council, Inc. ${ }^{37}$ a unanimous Court established a two-pronged test to evaluate an agency position presented as a legislative rule. At step one, a court determines whether the statute is ambiguous. If the court determines that the statute is not ambiguous, then it applies the plain meaning of the statute regardless of the agency's interpretation. If the court finds the statute ambiguous on its face, it moves to step two: If the court finds the agency's interpretation reasonable, it must defer to the agency position. ${ }^{38}$

The battleground of Chevron is step one. Almost any term of any statute arguably can be ambiguous; courts often divide over whether a term is ambiguous or not. ${ }^{39}$ In addition, the Supreme Court Justices disagree as to whether the "traditional canons of statutory construction," such as legislative history, may be consulted in order to determine whether or not a statute is ambiguous. ${ }^{40}$ Once a court determines that a statute is ambiguous, the agency almost always "wins" in step two. At that point, the task for the court is simply to evaluate the reasonableness of the agency's decision; and because a "reasonableness test" has a relatively low threshold, in that the agency position does not have to be the only

must be given to the decisions of an administrative agency applying a statute to the facts and that such decisions can be reversed only if without rational basis .... However, there is an impressive body of law sanctioning free substitution of judicial for administrative judgment when the question involves the meaning of a statutory term.

Pittston Stevedoring Corp. v. Dellaventura, 544 F.2d 35, 49 (2d Cir. 1976) (footnotes omitted), aff'd sub nom. Northeast Marine Terminal Co. v. Caputo, 432 U.S. 249 (1977). In Pittston, the court declined to defer to the administrative agency review board because it believed that the role of interpreting congressional legislation belonged to the courts. 544 F.2d at $48-49$.

37. 467 U.S. 837 (1984).

38. Id. at 844 .

39. "Ambiguity seems to have taken on epidemic proportions." Panel Discussion, Judicial Review of Administrative Action in a Conservative Era, 39 ADMIN. L. REV. 353, 362 (1987) (statement of Kenneth W. Starr). For examples of instances where ambiguity is disputed, see EEOC v. Commercial Office Prods. Co., 486 U.S. 107, 126 n.1 (1988) (Stevens, J., dissenting) (finding the word "termination" unambiguous, the dissent would not have deferred to the EEOC interpretation); Chemical Mfrs. Ass'n v. Natural Resources Defense Council, Inc., 470 U.S. 116, 139-40 (1985) (Marshall, J., dissenting) (finding the term "modify" unambiguous, the dissent would not have deferred to the EPA).

40. See Farina, supra note 6 , at $460 \mathrm{nn} .41-42$. See also INS v. Cardoza-Fonseca, 480 U.S. 421, 452-53 (1987) (Scalia, J., concurring in judgment) (disapproving of the majority's willingness to examine legislative history as a basis for inposing an interpretation of the statute at variance with its otherwise clear language). 
acceptable construction of the statute, ${ }^{41}$ the court almost always defers to the agency when it reaches step two of the Chevron test. ${ }^{42}$

Such a sweeping deference principle could greatly circumscribe substantive judicial review of agencies' interpretations and implementations of statutes and regulations. It is this grant of considerable discretion and power to the agencies by the extreme deference principle set forth in Chevron that has created one of the biggest debates of administrative law. ${ }^{43}$ Indeed, the scope of Chevron's extreme deference doctrine has been debated by the Supreme Court Justices. ${ }^{44}$

Whereas Skidmore utilized a supervisory approach to judicial deference, Chevron marked a significant move toward the checks and balances approach, ${ }^{45}$ thus perpetuating the confusion as to the appropriate level of deference to agency interpretations. Because Chevron is a more recent decision and has an alluring simplicity, many courts and scholars consider Chevron to be the preeminent decision addressing the relationship between the courts and administrative agencies. ${ }^{46}$ However, a careful examination of the Skidmore legacy reveals that the deference principle of Skidmore has been consistently applied by the Supreme Court without criticism. ${ }^{47}$ Chevron and Skidmore can in fact co-exist, because the deference levels they articulate apply to different types of agency action. The extreme deference of Chevron applies

41. See Farina; supra note 6 , at 454.

42. See Panel Discussion, supra note 39, at 361, 366 (statement of Kenneth W. Starr).

43. See generally KenNETH C. DAVIS, ADMINISTRATIVE LAW OF THE EIGHTIES: 1989 SUPPLEMENT TO ADMINISTRATIVE LAW TREATISE 518-22 (1989) (discussing how the Chevron Court overlooked $\$ 706$ of the Administrative Procedure Act and violated its constitutional duty to review agency action); Farina, supra note 6 (discussing Chevron and the "constitutional unease" about the allocation of power in the administrative state); Panel Discussion, supra note 39 (discussing the strong and weak readings of Chevron); Cass R. Sunstein, Law and Administration After Chevron, 90 Colum. L. REv. 2071 (1990) (discussing the limitations on the Chevron principle by other forms of statutory construction).

44. See Dole v. United Steelworkers of Am., 494 U.S. 26 (1990); INS v. Cardoza, 480 U.S. 421 (1987).

45. Starr, supra note 33 , at 306.

46. See id. at 307 . Most commentators agree on the persuasive and contagious effect of the Chevron decision. See Panel Discussion, supra note 39, at 356 (statement of Ronald M. Levin), 358 (statement of Kenneth W. Starr); Antonin Scalia, Judicial Deference to Administrative Interpretations of Law, 1989 DUKE L.J. 511, 512.

47. See infra note 116. 
to legislative rules; the cautious deference of Skidmore applies to interpretive rules.

The recent Supreme Court case of Equal Employment Opportunity Commission v. Arabian American Oil Co. (Aramco) ${ }^{48}$ presented competing views on the relationship between Chevron and Skidmore. In rejecting the Equal Employment Opportunity Commission's (EEOC) interpretation of Title VII, the Aramco majority applied a Skidmore analysis. Relying on factors established in Skidmore and subsequent decisions applying Skidmore, the majority found the EEOC's position unpersuasive and therefore entitled to little weight. Although the dissenting Justices did find the EEOC's position persuasive, their Aramco opinion and votes in other cases indicated that they agreed with the majority's view that Skidmore articulates the appropriate level of deference for interpretive rules. ${ }^{49}$ In contrast, the concurring Justice would have applied the two-step Chevron analysis. Finding the statute ambiguous under step one of the Chevron analysis, and the agency interpretation unreasonable under step two, the concurring Justice, like the majority, would not have deferred to the EEOC. Thus although they both declined to defer to the EEOC, the inajority and the concurrence applied different deference principles in reaching this result.

This Note examines the role Skidmore has played in the evolving principles of judicial deference in administrative law. It discusses, in particular, how the Chevron deference principle has affected the way Skidmore has been applied in the lower courts since Chevron. The Note then focuses on Aramco and its application of the Skidmore and Chevron principles. The factions of the Aramco Court suggest competing approaches to judicial deference and to the role of Skidmore. This Note argues that Skidmore deference is not only still a viable doctrine, but is also a necessary component of the court-agency relationship.

Part I focuses on the Skidmore case and highlights its important language with respect to judicial deference to agencies. It discusses the important case of General Electric Co. v. Gilbert, ${ }^{50}$ which revived a then-dormant Skidmore doctrine. Part I then describes how Skidmore has been adopted as the guide for the

48. 111 S. Ct. 1227 (1991).

49. See infra Section III(C).

50. 429 U.S. 125 (1976). 
courts to use to determine the proper level of deference to accord an interpretive rule. Part II discusses the erosion of the Skidmore doctrine. First, it comments on the courts' especially interesting applications of Skidmore in conjunction with the Chevron analysis, which effectively transforms Skidmore into a reasonableness test. ${ }^{51}$ Then, it evaluates the view-based on the beliefs that the distinction between legislative and interpretive rules is no longer important, and the demand for consistency in agency interpretations is no longer pressing - that Skidmore principles are no longer relevant to courts' deference determinations. Part III focuses on Aramco, the most recent Supreme Court case to address what role Skidmore should play in the deference debate. It also addresses the concurrence's mistaken view that Skidmore is no longer significant to deference principles because of the erroneous conclusion that the distinction between legislative and interpretive rules has eroded. Finally, Part IV discusses the importance of maintaining the distinction between legislative and interpretive rules. It also comments on the significance of Skidmore in this arena. This Note concludes that whereas Chevron is the authoritative case on deference to legislative rules, Skidmore is its counterpart for interpretive rules.

\section{SKIDMORE V. SWIFT \& CO.}

A. Skidmore's Language

The "most helpful and the most authoritative opinion on the legal effect of interpretive rules is Skidmore v. Swift \& Co."s2 At the time of the enactment of the Fair Labor Standards Act

51. The cases used as illustrations are from both before and after Aramco. A comparison of the cluster of cases citing Skidmore after Aramco, to the cases citing Skidmore after Chevron but before Aramco, did not reveal any particular trend in the application of Skidmore. The courts did not apply Skidmore differently after Aramco. Compare Dalheim v. KDFW-TV, 918 F.2d 1220, 1228 (5th Cir. 1990) with Greenwood Trust Co. v. Massachusetts, 776 F. Supp. 21, 36 n.38 (D. Mass. 1991), rev'd on other grounds, 971 F.2d 818 (1st Cir. 1992) (both decisions applying Skidmore analysis) and compare General Motors Corp. v. Ruckelshaus, 742 F.2d 1561, 1564-72 (D.C. Cir. 1984), cert. denied, 471 U.S. 1074 (1985) with Wagner Seed Co. v. Bush, 946 F.2d 918, 922 (D.C. Cir. 1991), cert. denied, 112 S. Ct. 1584 (1992) (both decisions rejecting Skidmore analysis).

52. 2 DAvis, supra note $7, \S 7.10$, at 50; see also Autrey v. Potlatch Corp., No. C-89-3695-SBA, 1992 U.S. Dist. LEXIS 12548, at *13 (N.D. Cal. Aug. 18, 1992) (commenting that Skidmore is the "most comprehensive statement of the role of interpretative rulings."). 
(FLSA), ${ }^{53}$ Congress had not established an administrative factfinding body for wage and lour cases, so the courts adjudicated these claims. However, Congress had created a position for an Administrator who had the power to enforce employer compliance with the FLSA, but not the power to make rules. This Administrator set forth his views of the application of the Act in interpretive bulletins and informal rulings. ${ }^{54}$ These documents provided a practical guide to employers and employees as to how the Administrator would seek to enforce and apply the Act. In the bulletin relevant to the issue of this case, the Administrator thought the "inactive duty"s5 problen called for a flexible solution, and le suggested guidehines for applying the overtime provisions of the FLSA. ${ }^{56}$ In choosing to adopt and apply the Administrator's interpretation, ${ }^{57}$ the Court articulated the proper role of interpretive rulings and their legal effect.

The Court noted that there was "no statutory provision as to what, if any, deference courts should pay to the Administrator's conclusions." ${ }^{\text {s8 }}$ It explained that although the Administrator's interpretation could not bind a court, his opimion carried weight because of several considerations: first, the Administrator based his construction of the Act on specialized experience and a broad investigation; second, the guidelines created by the Administrator would establish pohicy on behalf of the government and demonstrated the application of the Act; and finally, the existence of agency guidelines, if adopted by the Court, would allow the Act to be enforced consistently. ${ }^{59}$

In light of the above, the Court concluded that:

53. 29 U.S.C. $\S 3201-219$ (1988).

54. Skidmore, 323 U.S. at 138 (citation omitted).

55. "Inactive duty" refers to the hours during which the plant workers were required to stand by at assigned posts to answer fire alarms that might occur that evening. This responsibility was part of the general fire hall duties, and was required of each worker three or four nights a week. During this time, the workers often slept or played dominoes. The issue in the case was whether the workers were entitled to overtime compensation for part of this time under the FLSA. Skidmore v. Swift \& Co., 323 U.S. 134, 135-36 (1944).

56. Id. at 138.

57. However, the Court reversed and remanded the case to the district court because although the district court did consider the Administrator's opinion, the court's decision rested on an erroneous conclusion of law with respect to the meaning of "inactive duty." Id. at 140.

58. Id. at 139.

59. Id. at 139-40. 
the rulings, interpretations and opinions of the Administrator under this Act, while not controlling upon the courts by reason of their authority, do constitute a body of experience and informed judgment to which courts and litigants may properly resort for guidance. The weight of such a judgment in a particular case will depend upon the thoroughness evident in its consideration, the validity of its reasoning, its consistency with earlier and later pronouncements, and all those factors which give it power to persuade, if lacking power to control. ${ }^{60}$

The Skidmore decision assumed an important role in administrative law because of this language with respect to interpretive rules.

\section{B. Skidmore's Affirmation}

In General Electric Co. v. Gilbert, ${ }^{61}$ the Supreme Court rehed on Skidmore in declining to defer to the EEOC. ${ }^{62}$ In that case, the Court's analysis of the relevant section of Title VII was inconsistent with an EEOC guideline interpreting that section. ${ }^{63}$ In resolving this conflict, the Court stated that Congress did not grant the EEOC rulemaking power; therefore, this ruling and any ruling of the EEOC was an interpretive one. ${ }^{64}$ Thus although the EEOC interpretive ruling was entitled to consideration by the Court, it had less persuasive power than "administrative regulations which Congress has declared shall have the force of law, or . . . regulations which under the enabling statute may theinselves supply the basis for imposition of liability." evaluated the role of interpretive rules in courts' evaluations of

60. Id. at 140.

61. 429 -U.S. 125 (1976).

62. Id. at $141-43$.

63. Gilbert involved a disability plan of an employer which allegedly violated Title VII because it failed to cover pregnancy-related disabihties. Although the EEOC guideline interpreted the Act to require pregnancy-related disability benefits to be available on the same terms as other temporary disability benefits, $i d$. at 140-41, the Supreme Court upheld General Electric's disability plan, stating that a pregnancy exclusion was not gender-based discrimination and thus was not covered by Title VII, id. at 145-46. In 1978, Congress amended Title VII to include a cause of action for pregnancy discrimination: "Tlie terms 'because of sex' or 'on the basis of sex' include, but are not limited to, because of or on the basis of pregnancy, childbirth, or related medical conditions . . ." 42 U.S.C. \& $2000(\mathrm{e})(\mathrm{k})$ (1988).

64. Gilbert, 429 U.S. at 141; see also Autrey v. Potlatch Corp., No. C-89-3695-SBA, 1992 U.S. Dist. LEXIS 12548, at *12-13 (N.D. Cal. Aug. 18, 1992).

65. Gilbert, 429 U.S. at 141 (citations omitted). 
statutes and in their measurement of the rules' persuasive force. Although the Gilbert Court did not "wholly discount the weight" of the EEOC guideline, it concluded that the guideline did "not receive high marks when judged by the standards enunciated in Skidmore. ${ }^{36}$

With respect to adıninistrative law, Gilbert did not make new law; rather, it confirmed the fundamental distinction between legislative and interpretive rules. ${ }^{67}$ Gilbert firmly grounded Skidmore as a statement of authority on the necessary degree of deference to, and the persuasive power of, interpretive rulings. Gilbert also demonstrated how courts could use the thorougliness, validity, and consistency factors delineated in Skidmore as guidelines in measuring the appropriate weight to assign to agency interpretations. ${ }^{68}$ Altlough not addressed in Skidmore, contemporaneousness is another factor Gilbert instructed courts to consider when deciding if deference is appropriate.

\section{Skidmore's Legacy}

Skidmore's discussion of the role of interpretive rules as a guide for statutory interpretation has been affirmed repeatedly by the courts. ${ }^{69}$ "To the extent that a . . court finds in the interpretations an analogy useful in deciding the case before it, it may rely on the interpretation as persuasive evidence of both Congress's legislative intent and the Secretary's regulatory intent., ${ }^{370}$ The interpretive rules "constitute a body of experience and informed judgment to which courts and litigants may properly resort for guidance." ${ }^{.71}$ At the same tinie, Skidmore's emphasis on the nonbimding nature of interpretive rules has also been affirmed by the courts. $^{72}$

66. Id. at 143. The Court concluded that the EEOC guideline did not "fare well" under this standard. $I d$. at 142 . The Court found first, that the guideline was not a contemporaneous interpretation of Title VII, and second, that the guideline contradicted an earher agency position. Id. Both of these factors decreased the validity of the guideline and therefore its persuasive effect on the Court.

67. See 2 DAVIS, supra note $7, \S 7.8$, at 41 .

68. For examples of decisions applying Skidmore as a guide, see infra notes 83-88.

69. See, e.g., Prince v. Sullivan, 933 F.2d 598, 602 (7th Cir. 1991); Kohlhein v. Glynn County, 915 F.2d 1473, 1477 n.20 (11th Cir. 1990); Chamberhn v. 101 Realty, Inc., 915 F.2d 777, 781-82 (1st Cir. 1990).

70. Dalheim v. KDFW-TV, 918 F.2d 1220, 1228 (5th Cir. 1990).

71. Skidmore, 323 U.S. at 140.

72. See, e.g., Dalheim, 918 F.2d at 1228; Greenwood Trust Co. v. Massachusetts, 776 
In Skidmore, the Court explained the bases for deferring to an interpretive rule of an agency: first, an agency administrator's rulings are made "in pursuance of official duty, based upon more specialized experience and broader investigations and information than is likely to come to a judge in a particular case",73 and second, an agency determines policy on behalf of the government and provides guidance for the enforcement of the statute. ${ }^{74}$ In addition, the Court noted that its acceptance of the interpretation would allow for consistent application of the Act. ${ }^{75}$

In the majority of cases, there will be sufficient grounds for deference as most agencies have experience or expertise in interpreting the statutes they are charged to administer. Nonetheless, courts will not merely defer to agency interpretations, ${ }^{76}$ rather, they will evaluate the statutes at issue, and will examine agency interpretations to consider their persuasiveness. The Skidmore Court discussed the factors to be considered when evaluating the persuasive power of an interpretive rule: the thoroughness of the agency's decision to issue the rule, the validity of the agency's reasoning in making sucl a choice, and the consistency of the interpretive rule at issue witl earher pronouncements by the agency on the sanie topic." The Court added that other factors to be considered are those "whicl give [the rule] power to persuade, if lacking power to control.",78

Relying on this language in Skidmore, courts have considered factors not enumerated in Skidmore when evaluating the persuasive weiglit of an agency interpretation. For exaniple, in Gilbert, an agency interpretation gained persuasive value when it was enacted contemporaneously with the statute. ${ }^{79}$ In other cases, agency interpretations were persuasive if consistent with the overall congressional purpose of the statute. ${ }^{80}$ In still other cases, agency

F. Supp. 21, 36 n.38 (D. Mass. 1991) (agency interpretations are entitled to careful consideration but not to conclusive effect), rev'd on other grounds, 971 F.2d 818 (1st Cir. 1992).

73. Skidmore, 323 U.S. at 139 .

74. Id. at $139-40$.

75. Id. at 140.

76. See Bureau of Alcohol, Tobacco, \& Firearms v. Federal Labor Relations Auth., 464 U.S. 89, 97 (1983) (stating that courts must not "rubber-stamp" administrative decisions).

77. Skidmore, 323 U.S. at 140.

78. Id.

79. General Elec. Co. v. Gilbert, 429 U.S. 125, 141 (1976).

80. See, e.g., West v. Bowen, 879 F.2d 1122, 1131 (3d Cir. 1989); Wilcox v. Ives, 864 
expertise was another reason to defer to interpretive rules, ${ }^{81}$ the rationale being that with the technical administration of a statute, agencies may be better equipped than courts to determine the way a statute should be interpreted and applied. ${ }^{82}$

Courts have relied repeatedly on Skidmore deference principles to evaluate the soundness of an agency interpretation. ${ }^{83}$ Some courts weigh the thoroughness or validity factors, ${ }^{84}$ whereas others look to policy considerations ${ }^{85}$ and the congressional purpose underlying the statute. ${ }^{86}$ However, the overwhelming majority of cases equate persuasiveness of the agency interpretation with consistency $^{87}$ and contemporaneousness. ${ }^{88}$ In all of these cases, if the

F.2d 915, 924-25 (1st Cir. 1988); Barnett v. Weinberger, 818 F.2d 953, 962-63 (D.C. Cir. 1987); Greenwood Trust Co. v. Massachusetts, 776 F. Supp. 21, 36 n.38 (D. Mass. 1991), rev'd on other grounds, 971 F.2d 818 (1st Cir. 1992).

81. See, e.g., Baltimore Gas \& Elec. Co. v. National Resources Defense Council, Inc., 462 U.S. 87, 103 (1983); United States v. Doe, 960 F.2d 221, 225 (1st Cir. 1992); Greenwood, 776 F. Supp. at 36 n.38. The recent flurry of federal cases analyzing the retroactive application of $\S 102$ of the Civil Rights Act of 1991, the compensatory damages provision, illustrates how a court may evaluate "agency expertise." In order to clarify the proper interpretation of the Act, the EEOC issued a Policy Guidance recommending that $\S 102$ be applied prospectively only. See EEOC Policy Guidance on Retroactivity of Civil Rights Act of 1991, Daily Labor Rep. (BNA), Jan. 2, 1992, at D1; see also Croce v. V.I.P. Real Estate, 786 F. Supp. 1141, 1144 (E.D.N.Y. 1992); United States v. Department of Mental Health, 785 F. Supp. 846, 848 n.2 (E.D. Cal. 1992). In arriving at this conclusion, the EEOC evaluated the principle of retroactivity and examined the leading Supreme Court decisions on the subject. Noting that the "EEOC's expertise does not encompass analysis of Supreme Court cases," at least one district court has declined to defer to the agency's interpretation of the Act. See Crumley v. Delaware State College, 797 F. Supp. 341, 347.(D. Del. 1992). For other decisions stating that the courts, rather than the EEOC, are the experts in evaluating a traditional tool of statutory construction such as retroactivity, see Ayala-Chavez v. INS, 945 F.2d 288, 294 (9th Cir. 1991); Aiken v. Bucks Assoc. for Retarded Citizens, No. 91-2672, 1992 U.S. Dist. LEXIS 9925, at *37 (E.D. Pa. July 4, 1992); Kennedy v. Fritsch, 796 F. Supp. 306, 311-12 (N.D. Iil. 1992); Jackson v. Bankers Trust Co., 88 Civ. 4786, 1992 U.S. Dist. LEXIS 6290, at *11-12 (S.D.N.Y. Apr. 27, 1992).

82. See St. Luke's Hosp. v. Secretary of Health \& Human Servs., 810 F.2d 325, 331 (1st Cir. 1987).

83. See id., 810 F.2d at 331 ; Greenwood, 776 F. Supp. at 36 n.38; Flagstaff Medical Ctr. v. Sullivan, 773 F. Supp. 1325, 1344 (D. Ariz. 1991), aff'd in part, rev'd in part, 962 F.2d 879 (9th Cir. 1992).

84. See, e.g., Miree Constr. Corp. v. Dole, 930 F.2d 1536, 1541 (11th Cir. 1991); Wilshire Westwood Assocs. v. Atlanta Richfield Corp., 881 F.2d 801, 809 (9th Cir. 1989); Barnett, 818 F.2d at 962; Flagstaff, 773 F. Supp. at 1344-45; Westmiller v. Sullivan, 729 F. Supp. 260, 265 (W.D.N.Y. 1990).

85. See, e.g., West v. Bowen, 879 F.2d 1122, 1127 (3d Cir. 1989).

86. See, e.g., id. at 1131; Wilcox v. Ives, 864 F.2d 915, 924-25 (1st Cir. 1988); Barnett, 818 F.2d at 962-63; Greenwood Trust Co. v. Massachusetts, 776 F. Supp. 21, 36 n.38 (D. Mass. 1991).

87. See, e.g., West, 879 F.2d at 1134 (Mansinann, J., concurring in part, dissenting in 
court was persuaded that the agency satisfied the factors, then it would afford the agency interpretation a level of persuasive force in its decision. Acknowledging this persuasive force is a type of judicial deference. ${ }^{89}$

The concept embodied in Skidmore has had a profound impact on judicial review of agency rules. Even without rulemaking authority, an agency may state in an interpretive rule how it anticipates it will apply a statute. However, such an interpretive rule cannot bind the courts as it is not based on delegated lawmaking authority from Congress. A Court nay, if persuaded by the agency's reasoning, adopt the interpretive rule. But if not persuaded, a court may substitute its own judginent for that of the agency in administering the statute.

\section{THE EROSION OF SKIDMORE V. SWIFT \& CO.}

A. The Skidmore/Chevron Relationship: Transforming Skidmore into a Reasonableness Test

In 1984, the Supreme Court, in Chevron U.S.A. Inc. v. Natural Resources Defense Council, Inc. ${ }^{50}$ introduced a broad principle of judicial deference comprised of a two-prong test that evaluates an agency interpretation as established by a legislative rule. However, soine courts have applied the Chevron test witliout regard to the type of agency rule at issue, thus applying the deference of Chevron, instead of Skidmore, to interpretive rules. Consequently, Skidmore deference has at times been in danger of being replaced by the Chevron doctrine.

The then-fifty-year old case of Skidmore v. Swift \& Co. could easily have been overlooked or even overruled after the Chevron decision; but, in fact, neither of these events occurred. This Part evaluates how Skidmore has been invoked since the Chevron revolution. It discusses how Skidmore las been molded into a reason-

part) (collecting Third Circuit cases so holding); Wilcox, 864 F.2d at 924-25; Barnett, 818 F.2d at 960-61; St. Luke's Hosp., 810 F.2d at 331; General Motors Corp. v. Ruckelshaus, 742 F.2d 1561, 1565 n.7 (D.C. Cir. 1984); Flagstaff, 773 F. Supp. at 1339.

88. See, e.g., EEOC v. Arabian Am. Oil Co., 111 S. Ct. 1227, 1235 (1991); General Elec. Co. v. Gilbert, 429 U.S. 125, 142 (1976); Barnett, 818 F.2d at 960-61; Westmiller, 729 F. Supp. at 265.

89. However, the levels of 'deference vary depending on the type of rule that the court is reviewing. See supra text accompanying notes 7-24.

90. 467 U.S. 837 (1984). 
ableness test and, in soine decisions, incorporated into the second step of the Chevron analysis.

The simplicity and clarity of the Chevron two-prong test were welcomed by courts that had previously struggled to articulate a deference standard. However, the breadth of the Chevron doctrine soon became a central debate in administrative law."1 The Court itself became engaged in both limiting and expanding the scope of Chevron. ${ }^{92}$

As discussed earher, Chevron was a revolutionary case in defining judicial deference to agency interpretations promulgated as legislative rules..$^{93}$ If a statute is ambiguous, then a court must defer to any reasonable interpretation that the agency advocates. ${ }^{94}$ This test specifically applies to "legislative regulations," where Congress delegated explicit or imphicit authority to agencies to elucidate specific provisions of statutes through their rulemaking power..$^{5}$ Lower courts have cited Skidmore while engaging in step two of the Chevron analysis, the reasonableness inquiry. ${ }^{96}$

Typically, a court reviewing an agency rule, regardless of whether such rule is legislative or interpretive, engages in a Chevron discussion because of the pervasiveness of the Chevron doctrine. ${ }^{97}$ Once a court is satisfied that a statute is sufficiently ambiguous $^{98}$ so as to warrant a thorough investigation by the court into the statute's legislative history and intent, the court moves on to evaluate the reasonableness of the agency interpretation. During

91. See supra note 43 and accompanying text.

92. For decisions limiting Chevron, see supra note 44; for decisions expanding the scope of Chevron, see Mississippi Power \& Light Co. v. Mississippi ex rel Moore, 487 U.S. 354, 381-83 (1988) (Scalia, J., concurring in judgment); Young v. Community Nutrition Inst., 476 U.S. 974,981 (1986).

93. In Chevron, the EPA promulgated a regulation defining the terms of a statute pursuant to a congressional grant of power to make rules. The agency's definition of the term "stationary source" was challenged by the Natural Resources Defense Council, and the Court reviewed the validity of the agency's construction. 467 U.S. at 837 .

94. See supra text accompanying note 38 .

95. Chevron, 467 U.S. at 844.

96. See, e.g.; Evans v. Commissioner of Me. Dept. of Human Servs., 933 F.2d 1, 7 (1st Cir. 1991).

97. There are, however, some courts that refrain from invoking Chevron merely because agency action is involved. These courts are usually the same ones that mamtain a distinction between legislative and interpretive rules. See, e.g., Flagstaff Medical Ctr. v. Sullivan, 773 F. Supp. 1325, 1343-44 (D. Ariz. 1991).

98. Determining whether or not a statute is ambiguous has been a source of conflict witlin the Supreme Court. See supra note 39. 
this step, the court will often look at the thoroughness of the agency's investigation, the validity of the agency's reasoning, and the consistency of the agency's current interpretation with earlier rulings-the exact criteria of the Skidmore persuasiveness test. In fact, many courts cite Skidmore as the authority for this evaluation. In these cases, courts' usages of the Skidmore analysis in conjunction with the Chevron test transform the Skidmore persuasiveness test into a reasonableness test, oftentimes resulting in the application of Chevron deference, reserved for legislative rules, to interpretive rules. ${ }^{99}$

However, the Skidmore persuasiveness test and the reasonableness inquiry of Chevron are not the same test substantively. The purpose of the Skidmore inquiry into an agency interpretation is to determine its persuasiveness. ${ }^{100}$ Persuasiveness is used to determine whether or not a court should adopt an agency interpretation; an agency inust convince the court of the validity of the agency's view. ${ }^{101}$ In contrast to the Skidmore persuasiveness test, the second step of the Chevron test evaluates the reasonableness

- 99. See DAVIS, supra note 43, at 505; see, e.g., Evans, 933 F.2d at 7; Miree Constr. Corp. v. Dole, 930 F.2d 1536, 1541 (11th Cir. 1991); Wilshire Westwood Assocs. v. Atlanta Richfield Corp., 881 F.2d 801, 809 (9th Cir. 1989); West v. Bowen, 879 F.2d 1122, 1134 n.1 (3d Cir. 1989) (Mansmann, J., concurring in part, dissenting in part); Wilcox v. Ives, 864 F.2d 915, 924-25 (1st Cir. 1988); St. Luke's Hosp. v. Secretary of Health \& Human Servs., 810 F.2d 325, 331 (1st Cir. 1987); see also Rubin v. Tourneau, Inc., 92 Civ. 0078, 1992 U.S. Dist. LEXIS 10009, at *10 (S.D.N.Y. July 9, 1992); Savko v. Port Auth. of Allegheny County, No. 87-2390, 1992 U.S. Dist. LEXIS 9201, at *11-12 (E.D. Va. June 26, 1992); Reynolds v. Frank, 786 F. Supp. 168, 169 (D. Conn. 1992).

100. See Barnett v. Weinberger, 818 F.2d 953, 964 (D.C. Cir. 1987); see also MDPhysicians \& Assocs. v. State Bd. of Ins., 957 F.2d 178, 186 n.9 (5th Cir. 1992) (relying on Skidmore in finding Department of Labor's opinions of persuasive value).

Many of the factors used by the Skidmore court to determine the persuasive power of an interpretive rule are the same as those used to determine if an agency action is arbitrary and capricious, the standard of judicial review provided by the Administrative Procedure Act. See 5 U.S.C. $\& 706$ (1988). Agency actions struck down as arbitrary and capricious are rules promulgated without thorough investigation or valid reasoning. See, e.g., Motor Vehicle Mfrs. Ass'n v. State Farm Mut. Auto. Ins. Co., 463 U.S. 29, 46-48 (1983); Citizens to Preserve Overton Park v. Volpe, 401 U.S. 402, 413-16 (1971); Greater Boston Tel. Corp. v. FCC, 444 F.2d 841, 850-51 (D.C. Cir. 1970), cert. denied, 403 U.S. 923 (1971). Agency positions that fluctuate frequently are also often struck down for arbitrariness. See, e.g., Nader v. Bork, 366 F. Supp. 104, 108-09 (D.D.C. 1973). Courts applying the arbitrary and capricious review are, in practical effect, assessing the persuasiveness of the agency's rulemaking.

101. Wilcox, 864 F.2d at 924 (agency must rely on the "persuasive power" of its argument) (quoting Mayburg v. Secretary of Health \& Human Servs., 740 F.2d 100, 106 (1984)); see also MDPhysicians, 957 F.2d at $186 \mathrm{n} .9$ (noting "persuasive value" of agency's opinion). 
of the agency's rule. The reasonableness inquiry requires that an agency simply present a coherent and rational interpretation of the statute to the court. The implication is that the agency does not have to "win over" or persuade the court, but rather that the court inust accept the agency interpretation unless it is unreasonable or defies common sense. ${ }^{102}$ There is, then, clearly a distinction between the depth of judicial inquiry under Skidmore and under Chevron: the Skidmore standard of review is much more difficult for an agency to satisfy.

The result of applying the Skidmore persuasiveness test in the second part of a Chevron analysis is twofold. First, because a court that finds an agency interpretation persuasive will most likely find that interpretation reasonable, one may question the harm of such an application. However, by imposing the persuasiveness test on agencies im the context of legislative rules, courts' evaluation of agency interpretations may be too intrusive. According to Chevron, agency interpretations with legislative force should be entitled to a high level of deference. An agency's rule is like a congressional statute-and the courts must respect the legislative will. Second, the transformation of the Skidmore criteria into a reasonableness test incorporates Skidmore into a Chevron analysis. The separate standards of deference were crafted fifty years apart from one another in factually discrete situations--the Skidmore doctrine fashioned for application to interpretive rules, and the Chevron doctrine for application in the context of legislative regulations. Incorporating Skidmore into Chevron dilutes the significance of Skidmore as the authority on how to evaluate interpretive rules. ${ }^{103}$ The courts must recognize that there is an impenetrable wall between legislative and interpretive rules, and that the standards of judicial deference set forth in Skidmore and Chevron are on opposite sides of it.

\section{B. No Use for Skidinore}

Two small but ascending factions advocate views that would significantly erode the future role of Skidmore. One faction suggests treating legislative and interpretive rules the same with re-

102. West, 879 F.2d at 1124; Flagstaff Medical Ctr. v. Sullivan, 773 F. Supp. 1325, 1338-39 (D. Ariz. 1991), affd in part, rev'd in part, 962 F.2d 879 (9th Cir. 1992).

103. See Flagstaff, 773 F. Supp. at 1344. 
gard to judicial deference, thus applying Chevron in all deference cases, and effectively rendering obsolete Skidmore's discussion concerning interpretive rules. The other faction suggests that consistency in interpretations is not necessary for judicial deference to an agency interpretation, thus minimizing the use of Skidmore as a persuasiveness test. This Section will address each of these views separately.

Although some jurists clearly believe that legislative and interpretive rules should no longer be treated differently with regard to judicial deference, few actually advocate the destruction of the distinction between legislative and interpretive rules. ${ }^{104}$ Rather, most courts implicitly reject the principle of treating the types of rules differently. The most prominent and widely used method of blurring the legislative/interpretive rule distimction is the application of a Chevron analysis when the rule involved is an interpretive one. ${ }^{105}$ In Chevron, the Court exphicitly stated that "legislative regulations,". such as the one in that case, were to be given controlling weight by the Court if they were reasonable. ${ }^{106}$ When courts adopt the extreme deference standard of Chevron for interpretive rules, they ignore the difference between the deference standard for legislative rules and the deference standard for interpretive rules:

The critical distinction between Chevron and Skidmore is that when applying the Skidmore deference principle, a court is always free to substitute its judgment for that of the agency. The court uses the Skidmore persuasiveness test to weigh the agency interpretation into its final determination of the proper construction of the statute at issue. The court may choose to adopt fully the agency's viewpoint, but "the choice is unequivocally the court's to make. Under Chevron, once the court finds a statute ambiguous, it must defer to a reasonable agency interpretation of that statute. This doctrine of compelled deference applies only to legislative rules. ${ }^{107}$ When a court explains that it is compelled to defer to an

104. For examples of judges who advocate the destruction of the distinction, see EEOC v. Arabian Am. Oil Co., 111 S. Ct. 1227, 1236 (1991) (Scalia, J., concurring in part and concurring in judgment); Wagner Seed Co. v. Bush, 946 F.2d 918, 922 (D.C. Cir. 1991), cert. denied, 112 S. Ct. 1584 (1992); U.S. Mosaic Tilè Co. v. NLRB, 935 F.2d 1249, 1255 n.6 (11th Cir. 1991), cert. denied, 112 S. Ct. 871 (1992).

105. See, e.g., Wagner Seed, 946 F.2d at 922.

106. Chevron, 467 U.S. at 844.

107. See supra notes 7-24 and accompanying text. 
interpretive rule, it ignores Skidmore and uses Chevron to supplant it. ${ }^{103}$ The merger of the different deference standards deflates the importance of Skidmore's role as the authoritative pronouncement on the legal effect of interpretive rules ${ }^{109}$ and negates the distinction between legislative and interpretive rules. ${ }^{10}$

The second approach to judicial deference that would erode the role of Skidmore focuses on the consistency component of Skidmore's persuasiveness test. A growing number of commentators have acknowledged the importance of policymaking considerations in weighing deference questions. ${ }^{111}$ When, in a statute to be implemented by an agency, Congress creates an ambiguity that cannot be resolved by the text, the legislative history, or the "traditional tools of statutory construction," the resolution of that ambiguity necessarily involves policy judgment. ${ }^{12}$ Because policy considerations can change over time depending on the pohtical process, it is argued that the consistency factor in evaluating the persuasiveness or reasonableness of an agency interpretation is diminished. ${ }^{113}$ These commentators urge the courts to recognize

108. See, e.g., General Motors Corp. v. Ruckelshaus, 742 F.2d 1561, 1564-72 (D.C. Cir. 1984), cert. denied, 471 U.S. 1074 (1985); EEOC v. Tortilleria La Mejor, 758 F. Supp. 585, 589 (E.D. Cal. 1991); see also Marshall J. Breger, Defining Administrative Law, 60 Geo. WASH. L. REV. 268, 274 n.47 (1991) (reviewing PETER L. STRAUSS, AN INTRODUCTION TO ADMINISTRATIVE JUSTICE IN THE UNITED STATES (1989)).

109. See supra text accompanying note 52 .

110. For a discussion detailing the differences between legislative and interpretive rules, see supra text accompanying notes 7-24.

111. Douglas W. Kmiec, Judicial Deference to Executive Agencies and the Decline of the Nondelegation Doctrine, 2 ADMIN. L.J. 269, $277-78$ (1988); Panel Discussion, Developments in Judicial Review with Emphasis on the Concepts of Standing and Deference to the Agency, 4 ADMIN. L.J. 113, 127 (1990) (comment of Stephen F. Willians); Starr, supra note 33 , at $308-09,312$.

112. See Scalia, supra note 46 , at 515. Justice Scalia is in fact critical of this reasoning as a basis for deference. He argues that the underlying reason for deferring to agencies is that when Congress leaves a gap in a statute, it is the intent of Congress to give the agency the power to fill that gap, and the courts should accordingly respect the agency construction of the statute. Id. at 516. This analysis fails to consider that an agency without an express delegation of legislative rulemaking power simply lacks the power to fill these gaps. For a decision demonstrating the application of Justice Scalia's approach, see Wilshire Westwood Assocs. v. Atlanta Richfield Corp., 881 F.2d 801, 809 (9th Cir. 1989) (citing Process Gas Consumers Group v. United States, 694 F.2d 778, 791 (D.C. Cir. 1982) (en banç), cert. denied, 461 U.S. 905 (1983)).

113. "While it is generally true that less deference should be accorded to administrative interpretations that lack consistency, an agency is not locked into the first interpretation it espouses." Sacred Heart Medical Ctr. v. Sullivan, 958 F.2d 537, 544 (3d Cir. 1992). 
the need for flexibility in agency action and the appropriate role of political participation in the administrative process. ${ }^{114}$

If courts were to relax the consistency factor of the Skidmore principle to allow agency interpretations that fluctuate to receive deference, Skidmore would lose some of its significance as a persuasiveness test. Of all of the persuasiveness criteria, consistency of the agency's position is the valuation most leavily relied on in measuring the persuasiveness of an interpretive rule; ${ }^{115}$ holding that consistency is not a necessary component to an evaluation of the persuasiveness of an agency's rule seriously undermines the usefulness of the Skidmore test.

The role of Skidmore in the courts could be considerably curtailed should either of these trends become accepted. A doctrine affording legislative and interpretive rules the same level of judicial deference would diminish Skidmore's significance as the guidepost for judicial deference to interpretive rules. Moreover, the possibility of decreasing the importance of consistency in determining the soundness of agency interpretations would detract from the position of Skidmore as a guide for determining the persuasiveness of agency rules.

\section{MAINTAINING THE SKIDMORE TRADITION: EEOC V. ARAMCO}

The Supreme Court has cited Skidmore seven times since Chevron. ${ }^{116}$ In each case, the authoring Justice quoted Skidmore approvingly and based his analysis im some part on Skidmore's discussion of interpretive rules-without applying the Skidmore analysis in conjunction with Chevron, or equating the thrust of Skidmore with a test for agency reasonableness. Rather, the Justices treated Skidmore as the authority on the legal effect of inter-

114. Scalia, supra note 46 , at 517 .

115. See supra note 87 and accompanying text. Consistency prevents arbitrary decisionmaking by the agency and provides notice to parties likely to be subject to agency regulation.

116. See EEOC v. Arabian Am. Oil Co. (Aramco), 111 S. Ct. 1227 (1991); Martin v. Occupational Safety \& Health Review Comm'n, 111 S. Ct. 1171, 1179 (1991); Ansonia Bd. of Educ. v. Philbrook, 479 U.S. 60,70 n.6 (1986); Local No. 93, Int'l Assoc. of Firefighters v. City of Cleveland, 478 U.S. 501, 518 (1986); Meritor Savings Bank v. Vinson, 477 U.S. 57, 65 (1986); Lowe v. SEC, 472 U.S. 181, 216, 220 (1985) (White, J., concurring in result); Mountain States Tel. \& Tel. Co. v. Pueblo of Santa Ana, 472 U.S. 237, 270 (1985) (Brennan, J., dissenting). 
pretive rules. As discussed in earlier portions of this Note, the significance attached to the Skidmore decision varies in the lower courts. However, the Justices' opinions elucidate the proper treatment of Skidmore. Aramco ${ }^{117}$ is the Court's most recent discussion of Skidmore deference. This Part discusses Aramco and the competing factions within the Court that illustrate the contemporary judicial deference debate.

\section{A. The Majority's View}

Ali Boureslan, a naturalized United States citizen, worked in Saudi Arabia for a subsidiary of the Arabian American Oil Company (Aramco), an American corporation. He was discliarged from his duties after working for the conipany for approximately five years. Boureslan brought suit against Arainco in federal court under Title VII, alleging that he was harassed and ultimately dismissed by Aramco because of his race, religion, and national origin. ${ }^{118}$

The district court dismissed Boureslan's claim for want of subject nuatter jurisdiction, and the Court of Appeals for the Fiftl Circuit affirmed. ${ }^{119}$ On certiorari, the Supreme Court affirmed, holding that Title VII did not apply extraterritorially to regulate the employment practices of U.S. companies that employ U.S. citizens abroad. ${ }^{120}$

Although Aramco raises complicated questions of international law and statutory construction, this Note confines its discussion of the decision to a domestic administrative law context. ${ }^{121}$ In

117. 111 S. Ct. 1227 (1991).

118. Id. at $1229-30$.

119. Boureslan v. Aramco, 653 F. Supp. 629 (S.D. Tex. 1987), aff'd, 857 F.2d 1014 (5th Cir. 1988), adopted on reh'g, 892 F.2d 1271 (5th Cir. 1990) (en banc).

120. $111 \mathrm{~S}$. Ct. 1227, 1236. The majority of the Court consisted of Chief Justice Rehnquist and Justices White, O'Connor, Kennedy, and Souter. Soon after the decision, its holding was effectively circumvented by Congress with the passage of the Civil Rights Act of 1991; that Act provides that Title VII does apply extraterritorially to United States citizens working abroad. See Sofferin v. American Airlines, 785 F. Supp. 780, 784 n.9 (N.D. Ill. 1992); McCullough v. Consolidated Rail, 785 F. Supp. 1309, 1315 (N.D. Ill. 1992); Conerly v. CVN Co., 785 F. Supp. 801, 805 n.6 (D. Minn. 1992). However, "the Supreme Court's discussion of the appropriate deference to be afforded to the EEOC guidelines remains valid." Crumley v. Delaware State College, 797 F. Supp. 341 , 347 n.7 (D. Del. 1992).

121. Despite the broad jurisdictional grant of Title VII, the Court refused to apply the statute extraterritorially without a "clear statement" from Congress authorizing this construction because of the presumption against extraterritoriality. The case also raised such important issues as separation of powers and international comity. 
Aramco, the EEOC argued that the Court should defer to the agency's interpretation of the statute. ${ }^{122}$ Although the Court found Title VII ambiguous, ${ }^{123}$ it did not agree with the EEOC's construction, and declined to defer to the agency position. ${ }^{124}$ The Court reasoned:

In General Electric Co. v. Gilbert, we addressed the proper deference to be afforded the EEOC's guidelines. Recognizing that "Congress, in enacting Title VII, did not confer upon the EEOC authority to promulgate rules or regulations," we held that the level of deference afforded "will depend upon the thoroughness evident in its consideration, the validity of its reasoning, its consistency with earlier and later pronouncements, and all those factors which give it power to persuade, if lacking power to control.' "125

In evaluating the EEOC's position under Skidmore's persuasiveness test, the Court found that the agency's interpretation of the statute was "neither contemporaneous with its enactment nor consistent since the statute came into law."126 While the Court did not "wholly discount the weight to be given to the 1988 [EEOC] guideline," it stated that the guideline's "persuasive value [was] limited when judged by the standards set forth in Skidmore."127

While the Court exphicitly stated that Title VII is ambiguous on its face with respect to its application outside of the United States, the Court did not even mention the possibility of applying Chevron deference in this case. Although the Court did not state its reason for not using a Chevron analysis, one can infer the reason from the opinion. First, the Court emphasized that Congress provided the EEOC with enforcennent and investigative powers, but not with rulemaking power. ${ }^{128}$ The conclusion that follows from this statement is that any ruling issued by the EEOC must be an interpretive one. ${ }^{129}$ Because these rulings were

122. Aramco, 111 S. Ct. at 1235. The EEOC's position encouraged extraterritorial application of Title VII. Id.

123. Id. at 1231 .

124. Id. at 1235 .

125. Id. (citation omitted) (quoting General Elec. Co. v. Gilbert, 429 U.S. 125, 141, 142 (1976) (quoting Skidmore v. Swift \& Co., 323 U.S. 134, 140 (1944))).

126. Id. These very concerns required the Court to reject the EEOC's interpretation of Title VII in Gilbert sixteen years earlier. See supra note 66.

127. Aramco, 111 S. Ct. at 1235.

128. Id.

129. Agencies without a delegated congressional grant of rulemaking power have no 
nonlegislative, the Court did not need to give the agency Chevron deference; instead, the Court could, and did, apply Skidmore deference principles. Second, the Court's action of freely substituting its interpretation for the agency's is consistent with a Skidmore, not a Chevron, analysis. The Court undertook an in-depth evaluation of Title VII and arrived at its own conclusion with regard to the statute's application. In light of the EEOC's conflicting position that Title VII could be applied abroad, the Court reviewed the EEOC interpretation to determine its persuasive value. Applying the Skidmore persuasiveness test to the agency position, 'the Court found that the agency's interpretation did not "fare well" and was not entitled to much weiglit. ${ }^{130}$

\section{B. The Concurrence's View}

In his concurring opinion, Justice Scalia differed from the majority only with regard to the method of determining the level of deference to be accorded to the EEOC's interpretation of Title VII. First, he criticized the majority's application of Gilbert; the case stood for a broader deference principle than the majority attributed to it. Second, he argued that a Chevron analysis should liave been used in this case, ${ }^{131}$ citing EEOC $v$. Commercial Office Products $C 0 .{ }^{132}$ Lastly, lie noted the competing relationship between a Chevron analysis and otler forms of statutory construction.

Justice Scalia criticized the majority's application of Gilbert as incorrect and misleading. He restated the majority's position as the view that the EEOC-not only with respect to the particular point

power to issue rules with legislative force. Even if there were any doubt as to this conclusion, it is evident that in this case the EEOC rulings were all interpretive in nature; the EEOC attempted to buttress its position before the Court with a 1989 Policy Statement supplemented by a 1975 letter from its general counsel, 1983 testimony by its chairman, and a 1985 decision by the Commissioner. Aramco, $111 \mathrm{~S}$. Ct. at 1235. The EEOC argued that all of these informal rulings professed that Title VII could be applied abroad. Id. Without question, these explanatory rulings are interpretive, and not legislative. See supra notes 15-16 and accompanying text. In addition to the fact that the EEOC las no authority to issue legislative rules, none of the agency's supporting documents were issued according to the rulemaking procedures mandated by the Administrative Procedure Act and therefore could not be "legislative rules." See Anthony, supra note 7 , at 1322 .

130. Aramco, 111 S. Ct. at 1235.

131. Id. at 1236 (Scalia, J., concurring in part and concurring in judgment).

132. 486 U.S. 107 (1988). 
at issue here, but apparently as a general matter-is not entitled to the deference normally afforded to administrative agencies under Chevron.$^{133} \mathrm{He}$ pointed out that Gilbert did not reason that the EEOC, singled out from other agencies, was not entitled to deference; rather, "the EEOC's guidelines like the guidelines of all agencies without explicit rulemaking power, could not be considered legislative rules and therefore could not be accorded deference." $" 134$

The distinction that Justice Scalia raised, while technically correct, is inconsequential. Gilbert did rely lieavily on Skidmore's analysis concerning interpretive rules. Broadly stated, the reasoning of the Gilbert opinion espouses nondeferential review for interpretive rules. But the Aramco Court's blanket denial of deference to the EEOC in particular does not disturb this concept. The EEOC has no rulemaking power, ${ }^{135}$ and therefore cannot promulgate legislative rules. ${ }^{136}$ It follows that all EEOC rulings are interpretive and thus not eligible for Chevron deference. The majority's implication that the EEOC in particular is not afforded Chevron deference like other agencies is correct. While Justice Scalia may have accurately described the apparent gap in the majority's logic, the resulting incongruence does not change the effect of the original discussion in Gilbert.

Far more provocative is Justice Scahia's advocacy of Chevron deference for the EEOC guidelines in the Aramco case. He asserted that "[i]n an era when our treatment of agency positions is governed by Chevron, the 'legislative rules vs. other action' dichotomy of Gilbert is an anachromsm"; ${ }^{137}$ and explained that "[t]he

133. Aramco, $111 \mathrm{~S}$. Ct. at 1236. It is not entirely clear that this is what the majority meant; but even if it is, the resulting error is innocuous. Some interpretations of Gilbert do espouse the view that the EEOC is not entitled to the same deference as other government agencies. See, e.g., I. Bennett Capers, Note, Sex(ual Orientation) and Title VII, 91 Colum. L. REv. 1158, 1185 n.117 (1991). This argument finds support from two postChevron cases, Ansonia Bd. of Educ. v. Philbrook, 479 U.S. 60, 69 n.6 (1986) and Local 93, Int'l Ass'n of Firefighters v. City of Cleveland, 478 U.S. 501, 517-18 (1986).

134. Aramco, $111 \mathrm{~S}$. Ct. at 1236 (emphasis in original). For a more complete discussion of Gilbert, see supra text accompanying notes 61-68.

135. See 42 U.S.C. $\& 2000(\mathrm{e})(4)$ (1988).

136. When an agency does not have authority to promulgate legally binding rules, the rulings of the agency are interpretive. Joseph v. Civil Serv. Comm'n, 554 F.2d 1140, 1154 n.26 (D.C. Cir. 1977).

137. Aramco, $111 \mathrm{~S}$. Ct. at 1236. Justice Scalia is the leading critic of the usefulness of maintaining the legislative/interpretive rule distinction. See supra at notes 104, 112-14 and accompanying text. 
case relied upon for the proposition that the EEOC's interpretations liave only the force derived from their 'power to persuade' was decided in an era when we were disposed to give deference (as opposed to 'persuasive force') only to so-called 'legislative regulations.' "'138

Justice Scalia's analysis clarified his position that Chevron should be the sole authority on judicial deference; lis statements, however, do not accurately reflect the current state of the law. First, Chevron involved a legislative rule, and the Court has not expanded the doctrine to encompass all other agency action; ${ }^{139}$ thus, the assertion that Chevron governs judicial treatment of all agency action does not find support in Supreme Court precedent. In addition, while it is true that the "power to persuade" type of deference which Justice Scalia criticized was developed sixty years prior to Chevron, it is still broadly applied and lias not been overruled by the Court. ${ }^{140}$ Indeed, the Aramco majority relied on Skidmore's reasoning, and moreover, had invoked Skidmore just one week before the Aramco decision, in an opinion that Justice Scaha joined. ${ }^{141}$

Justice Scalia supported his arguments that Gilbert stood for a limited principle and that Chevron should have been applied to the Aramco facts by referring to a decision issued three years prior to Aramco, EEOC v. Commercial Office Products Co. ${ }^{142}$ In Commercial Office Products, the Court said that "the EEOC's interpretation of ambiguous language need only be reasonable to be entitled to deference."143 Justice Scalia noted cogently that the language used in Commercial Office Products is similar to that in cases that follow Chevron. ${ }^{144}$ Disturbed that the Court failed to

138. Aramco, 111 S. Ct. at 1236.

139. Some courts have suggested that Chevron "deference should be accorded to agency adjudications. See, e.g., U.S. Mosaic Tile Co. v. NLRB, 935 F.2d 1249, 1255 n.6 (11th Cir. 1991), cert. denied, 112 S. Ct. 871 (1992).

140. In fact, the Court has reaffirmed its approval of the "power to persuade" deference of Skidmore six times since Chevron. See supra note 116.

141. See Martin v. OSHR, 111 S. Ct. 1171, 1179 (1991).

142. 486 U.S. 107 (1988). Justice Scalia did not join the majority opinion which deferred to the EEOC. Instead, he joined Justice Stevens's dissent which found no ambiguity in the meaming of the statute, which would have ended his inquiry under the Chevron test.

143. Id. at 115 .

144. Aramco, 111 S.Ct. at 1236 (Scakia, J., concurring). In looking at whether a statute is "ambiguous" or not, the Court engages in a traditional analysis to discern whether 
mention Commercial Office Products in its analysis, Justice Scalia declared that after Aramco "the state of the law regarding deference to the EEOC is left unsettled."145

In order to assess Justice Scalia's attack on the omission of Commercial Office Products from the majority's analysis, it is helpful to analyze that decision briefly. In Commercial Office Products, the Court did not mention Chevron. The Court's silence about Chevron could mean either that the Court was unaware of Chevron or that it made a conscious decision not to use the analysis from Chevron..$^{146}$ On the first point, the Court could not liave been unaware of Chevron. ${ }^{147}$ Secondly, the Commercial Office Products quote resembling Chevron language cites as its authority a pre-Chevron case, Oscar Mayer \& Co. v. Evans, as the basis of its analysis. ${ }^{148}$ Oscar Mayer, in turn, rehed on Griggs v. Duke Power $\mathrm{Co}^{149}$ in deferring to the EEOC. Griggs said that EEOC interpretations were entitled to "great deference." 150 However, in Gilbert, the Court reconciled Griggs" "great deference" witl its analysis of the EEOC guidelines in its discussion of the legal effect of interpretive rules. ${ }^{151}$ The Gilbert Court explained that it did not mean to say that EEOC guidelines are not entitled to "consideration in determining legislative intent," but rather that, since the guidelines were only interpretive rules, they could be accorded less weight than other rules that have the force of law. Gilbert explained that "[t]he most comprehensive statement of the role of interpretive ruhings such as the EEOC guidelines is found in

the meaning of the statute is clear on its face before it looks beyond the statute to legislative history or agency interpretations. Use of the term "ambiguous" in conjunction with "reasonable" does not automatically mean the Court is applying Chevron deference. The Court's hesitation to use Chevron deference, in both Commercial Office Products and Aramco, confirms that the Court continues to recognize and preserve the distinct deference standards of Chevron and Skidmore as applied to legislative and interpretive rules, respectively.

145. Id.

146. This analysis is borrowed from Kenneth Culp Davis's discussion of Chevron's apparent conflict with $\S 706$ of the Administrative Procedure Act. DAvIS, supra note 43, at $510-11$.

147. Id.

148. Commercial Office Prods., 486 U.S. at 115 (citing Oscar Mayer \& Co. v. Evans, 441 U.S. 750,761 (1979)).

149. 401 U.S. 424 (1971).

150. Id. at 434 .

151. General Elec. Co. v. Gilbert, 429 U.S. 125, 141 (1976). For a more complete discussion of Gilbert, see supra text accompanying notes $61-68$. 
Skidmore v. Swift \& Co."152 Commercial Office Products, then, contrary to Justice Scalia's interpretation, is not an example of the Court's acceptance of a Chevron analysis for EEOC guidelines; rather, it is an affirmation of a prior line of cases consistent with and relying on Skidmore. ${ }^{153}$.

Justice Scalia would decide the Aramco case as follows: he would assume that the EEOC was entitled to deference, and then apply a Chevron analysis. Agreeing with the majority in finding the statute ambiguous, Justice Scalia would move on to step two of the Chevron test. He noted that "deference is not an abdication, and it requires us to accept only those agency interpretations that are reasonable in light of the principles of construction courts normally employ." ${ }^{2154}$ Because there is a presumption against extraterritoriality in interpreting statutes, and the requirement that the intent of Congress to overcome this presumption be "clearly expressed," Justice Scalia would conclude that the agency interpretation of the statutory language to the contrary was not reasonable. $^{155}$

\section{The Dissent's View}

Led by Justice Marshall, the dissent ${ }^{156}$ agreed with the majority that the Skidmore standard of deference should be used in this decision; however, it disagreed with the majority's determination that the EEOC's interpretation was not entitled to persuasive weight. Quoting Commercial Office Products, Justice Marshall advocated deference to the interpretation of the EEOC because it was persuasive. ${ }^{157} \mathrm{He}$ emphasized the consistency of the EEOC

152. Gilbert, 429 U.S. at 141 (citations omitted).

153. In addition, the deference in Commercial Office Products rested on the EEOC's responsibility as primary enforcer of the statute. Kennedy v. Fritsch, 796 F. Supp. 306, 311 (N.D. Ill. 1992). The "logical foundation for [this] holding is porous"; the EEOC's power to sue under Title VII does not create a power "to tell the courts how to interpret the substantive provisions of that statute." Id. at 311 n.5.

154. Aramco, $111 \mathrm{~S}$. Ct. at 1237 (citing Cass R. Sunstein, Law and Administration After Chevron, 90 Colum L. REv. 2071, 2114 (1990)). Professor Sunstein's article provides an excellent analysis for fitting Chevron into the broader framework of statutory construction. He explains which canons of construction outweigh Chevron and which do not.

155. Id. (citing Sunstein, supra note 154, at 2114).

156. Id. at 1237 (Marshall, J., dissenting, joined by Blackmun and Stevens, JJ.).

157. Id. at 1245. Two of the three dissenting Justices in Aramco were in the majority in Commercial Office Products. 
position to apply Title VII extraterritorially, and the reinforcement of the EEOC imterpretation by the Department of Justice: ${ }^{.158}$ "In sum, there is no reason not to give effect to the considered and consistently expressed views of the two agencies [the EEOC and the Department of Justice] assigned to enforce Title VII.,159 Whereas the Aramco dissent does not discuss its view concerning deference to the EEOC as fully as do the majority or the concurrence, its apphication of Commercial Office Products and evaluation of the consistency of the agency's position indicate a Skidmore inquiry.

Another case decided one week before Aramco, Martin $v$. Occupational Health \& Safety Commission, ${ }^{160}$ further illummates the views of the Justices participating in the Aramco dissent. In that case, a unanimous Court ${ }^{161}$ held that a reviewing court should defer to the Secretary of the Department of Labor over the Occupational Safety and Health Review Commission when the interpretations of the two interpretive bodies conflict. ${ }^{162}$ Relying on Skidmore, the Court explained that although informal ruhings (such as the one in Martin) were not entitled to the same deference as legislative rules, they had persuasive force on judicial review: "A reviewing court may certainly consult them to deterinine whether the [agency] has consistently apphied the interpretation embodied in the citation, a factor bearing on the reasonable-

158. Id. Stating the position of the Justice Department, then-Assistant Attorney General Scalia testified before Congress that the framework of Title VII implied that it protected United States citizens employed anywhere in the world. Foreign Investment and Arab Boycott Legislation: Hearings Before the Subcomm. on International Finance of the Senate Comm. on Banking, Housing and Urban Affairs, 94th Cong., 1st Sess. 159, 165 (1975).

159. Aramco, 111 S. Ct. at 1246.

160. 111 S. Ct. 1171 (1991). Martin was decided on March 20, 1991; Aramco was decided on March 26, 1991.

161. It is interesting to note that Justice Scalia in fact joined the Court in its application of Skidmore just one week prior to his Aramco concurrence challenging the validity of Skidmore's deference principles.

162. Both are administrative bodies within the Department of Labor. 
ness of the [agency's] position." 163 This analysis is consistent with Skidmore, not Chevron, deference principles.

The analysis of the Court in Martin is consistent with that in Aramco. Although addressing different issues, the Court used Skidmore deference in both situations. Currently, seven of the Justices are of the view that Skidmore is still a viable doctrine. ${ }^{164}$

\section{THE REVIVAL OF SKIDMORE V. SWIFT \& CO.: PRESERVING THE DISTINCTION BETWEEN LEGISLATIVE AND INTERPRETIVE RULES}

Interpretive rules must be distinguished from legislative rules. ${ }^{165}$ Interpretive rules are not binding on the courts; courts are free to substitute their judgment for that of an agency in interpreting a statute. Legislative rules are supported by a congressional delegation of power to the agency; courts are not free to displace agency interpretations with their own. ${ }^{166}$ The fundamental distinction between legislative and interpretive rules is that legislative rules have the binding force of law and interpretive rules do not.

Keeping the legislative/interpretive rule distinction intact conforms with democratic principles and comphes with the law ${ }^{167}$ This is so for three reasons. First, general principles of separation of powers require the distinction. Second, the Administrative Procedure Act mandates different procedural requirements for the two types of rules. Third, the distinction preserves the legitimacy of agency actions.

163. Martin, $111 \mathrm{~S}$. Ct. at 1179. The Court's use of "reasonableness" and "persuasiveness" interchangeably creates confusion in this area. When applying a Chevron analysis, reasonableness is the appropriate term because it implies minimal review by the court. However, when a court is applying a Skidmore analysis, it should use Skidmore's language, namely persuasiveness, to define the agency's interpretation. The Martin Court's substitution of reasonableness for persuasiveness clouds the true meaning of the terms and the competing levels of judicial inquiry. See supra text accompanying notes 100-02.

164. The majority in Aramco, coupled with the majority in Commercial Office Products and bolstered by Martin's unanimous decision, indicate that all the Justices except Scalia and Thomas support the continued application of Skidmore's cautious deference. Whereas it is clear that Justice Scalia emphatically rejects such a standard, see supra note 137-38 and accompanying text, Justice Thomas's views on Skidmore deference are not yet clear.

165. See supra text accompanying notes 7-24.

166. See supra notes $37-42$ and accompanying text.

167. DAvis, supra note 43 , at 54 . 


\section{A. Separation of Powers}

Agencies can make legislative rules that create rights, impose obligations, and bind the public. Courts defer to these rules because the force behind them is derived from a congressional grant of power. When an agency promulgates an interpretive rule that creates rights, imposes obligations, or binds the public, it is violating the separation of powers doctrine, as it is acting witlout congressionally delegated legislative authority.

An agency may promulgate binding rules because Congress lias delegated its lawmaking power to the agency. When an agency enacts an interpretive rule, the source of the rule is the agency itself, not Congress; this necessarily limits the breadth of interpretive rulemaking. A representative democracy allows the public to elect representatives to legislate; legislative powers derive their force from the people. When an agency legislates without a grant of power from Congress (that is to say, when it creates a rule that is legislative in nature), and therefore without the permission of the public, it circumvents the fundamental role of public participation in the legislative process. ${ }^{168}$

When an agency enacts a rule without a congressional grant of power, that rule is necessarily an interpretive one. If a court defers to an interpretive rule, it is deferring to the agency and to the agency alone. ${ }^{169} \mathrm{~A}$ doctrine mandating blind deference to interpretive rules subjugates the federal courts to the whims of nonelected, politically appointed agency lieads. ${ }^{170}$ Clearly, by deferring to an interpretive rule, a court abandons its role to "say what the law is.".171

However, when a court defers to a legislative rule, the court is not abdicating its role to interpret the laws. Courts may not act as super-legislatures. Chevron requires courts to apply a statute the way Congress intended it to be apphed. ${ }^{12}$ Courts still interpret

168. Batterton v. Marshall, 648 F.2d 694, 703 (D.C. Cir. 1980).

169. There is an important difference between blind deference and active review by a court. A court may give an interpretive rule the force of law by applying a Skidmore analysis. In applying the Skidmore test, a court inay, once it actively evaluates the statute on its own and weighs the persuasive power of the agency's position, give the interpretive rule the force of law by deferring to it.

170. See Panel Discussion, supra note 39, at 369 (statement of Cass R. Sunstein).

171. See supra note 6.

172. See Chevron U.S.A. Inc. v. National Resources Defense Council, Inc., 467 U.S. 837, 842-44 (1984). 
the law, but are supposed to do so in a way that gives effect to congressional intentions. When a court defers to a legislative rule, the court is deferring to congressional intent; it was Congress's intent to delegate its lawmaking power to the agency. ${ }^{173}$

\section{B. Administrative Procedure Act}

In order for an agency to exercise its legislative rulemaking power validly, an agency must follow the rulemaking procedure of the Administrative Procedure Act (APA). When an agency seeks . to create an interpretive rule, on the other hand, it does not lave to follow these procedures. ${ }^{174}$ Congress provided for different procedural practices because it recognized a difference between the two types of rules.

The APA was enacted with the goals of fairness and protecting the public. ${ }^{175}$ It provides for due process in agency adjudications and for rulemaking hearings "on the record."176 Even its informal rulemaking procedures provide for extensive public participation in the rulemaking process. ${ }^{177} \mathrm{By}$ requiring agencies to follow the rulemaking procedure prescribed in the APA for legislative rules, Congress guaranteed the opportunity for public participation in the quasi-legislative process. Congress did not provide formal procedures for the interpretive rulemaking process because the rules do not affect the public in the same intimate ways as legislative ones. In addition, interpretive rules are not binding and are also more likely to be procedural ${ }^{178}$ or instructive ${ }^{179}$ in na-

173. See id. at 843-44 (describing Congress' gap-filling delegation to agencies).

174. 5 U.S.C. $\$ 553(\mathrm{~b})(\mathrm{A})$ (1988). However, Professor Anthony suggests that agencies should follow at least informal notice-and-comment procedures if they are in fact promulgating an interpretive rule or pohicy statement that effectively binds the public. See generally Anthony, supra note 7.

175. Batterton v. Marshall, 648 F.2d 694, 700-04 (D.C. Cir. 1980); see Panel Discussion, supra note 39 , at 368 (stateinent of Cass R. Sunstein).

176. 5 U.S.C. $\$ 553$ (c) (1988).

177. Informal rulemaking is done through a notice-and-comment process. 5 U.S.C. $\$ \S$ 551, 553 (1988). In theory, notice-and-comment works like this: An agency publislies its proposed rule in the Federal Register and invites comments from the public. Any person or organization may submit comments to the agency. The agency then considers the comments, and incorporates the public's ideas and suggestions for changes into the rule. The problem with notice-and-comment is that even though it is not as burdensome as formal rulemaking on the record, it still drains a considerable amount of agency resources. See generally Thomas O. McGarity, Some Thoughts on "Deossifying" the Rulemaking Process, 41 DUKE L.J. 1385 (1992).

178. See, e.g., Vietnam Veterans of Am. v. Secretary of the Navy, 843 F.2d 528, 
ture. Lastly, Congress recognized that courts would actively review interpretive rules, therefore guarding a nonparticipating public from overzealous admimistrators.

\section{Legitimacy}

In addition to APA requirements, it is simply not good practice for courts to defer to interpretive rules. The APA was enacted to establish ruleinaking and adjudicative procedures for the agencies to follow. Interpretive rules are explicitly exempt from these proceedings. If courts allow agencies to accomplish legislative ends through interpretive rules, courts allow agencies to circumvent the procedures set down by Congress. Agencies will inost certainly take advantage of this "looplole." This is not to suggest that agencies are power-grabbers, but rather that it would simply be easier for agencies to create rules without public "interference."180 Ruleinaking, as established by the APA, is complicated and timeconsuming, and requires extensive use of an agency's already limited resources. ${ }^{181}$ Even "informal" notice-and-comment can have profound draining effects on agencies. ${ }^{182}$ It is fairly safe to assume that given the choice, an agency would rather risk an inter-

538-39 (D.C. Cir. 1988); Southern Cal. Edison Co. v. Federal Energy Regulatory Comm'n, 770 F.2d 779, 783 (9th Cir. 1985); American Meat Inst. v. Bergland, 459 F. Supp. 1308, 1314 (D.D.C. 1978).

179. See, e.g., Taunton Mun. Lighting Plant v. Department of Energy, 669 F.2d 710, 714-15 (Temp. Emer. Ct. App. 1982); Gosman v. United States, 573 F.2d 31, 39 (Ct. Cl. 1978); see also McKenzie v. Heckler, 602 F. Supp. 1150, 1159 (D. Minn. 1985) (defining an interpretive rule as "one that simply explains and sets forth with greater specificity that which a statute already requires"), rev'd on other grounds, 787 F.2d 1216 (8th Cir. 1986).

180. See Anthony, supra note 7, at 1317-18; cf. Panel Discussion, supra note 39 at 368 (statement of Cass R. Sunstein):

[T] hose who are limited in their authority by law should not be the judge of those limits. Administrative agencies are constrained by statute, that is, law, and the mere fact that the statute is ambiguous shouldn't give the agency, of all people, the authority to decide on the meaning of the limitation. The cute way in which it's sometimes put is that foxes shouldn't guard henhouses. If Chevron is taken to mean that agencies judge the scope of their own authority, then one has precisely that problem.

181. Formal rulemaking requires an intensive trial-like hearing on the record; informal rulemaking requires an agency to propose rules to the public in order to solicit response and then to evaluate the various suggestions in order to re-work the rule. See 5 U.S.C. \& 553 (1988).

182. See Michael Asimow, Nonlegislative Rulemaking and Regulatory Reform, 1985 DUKE L.J. 381, 402-04; E. Donald Elliot, Re-Inventing Rulemaking, 41 DUKE L.J. 1490, 1494 (1992). 
pretive rule being challenged in the courts, than expend, up-front, the time, effort, and money to follow the APA procedure for legislative rules. ${ }^{183}$ If the interpretive rule is challenged, and a court defers to the rule with only the minimal "reasonableness" requirement of step two of the Chevron test, ${ }^{184}$ the agency may have a good chance of acquiring the force of law for that interpretive rule through the court's deference. Agencies can therefore achieve the effect of a binding rule without following, and in knowing violation of, the APA's mandated procedures. The probability of judicial deference therefore encourages the agencies to purposefully circumvent congressional statutes.

Preserving distinct levels of review for legislative and interpretive rules ensures that agencies will maintain legitimacy. The public presumes that agencies promulgate legislative rules according to the procedures in the APA, which allow for public participation. ${ }^{185}$ The public also presumes that if an agency enacts interpretive rules, which are in fact legislative in nature, without public participation, a court will review the agency interpretation of the statute using the cautious Skidmore persuasiveness test so as to protect the public from abusive agency action. ${ }^{186}$ Active and searching review by the courts discourages agencies from overstepping their boundaries and provides for open government and fairness in the administrative and regulatory system.

\section{CONCLUSION}

The significance of the Skidmore decision is twofold. First, it established the legal effect of interpretive rules. According to Skidmore, interpretive rules do not bind courts; rather, the rules provide guidance to courts seeking to interpret statutes. This principle is rooted in the legislative/interpretive rule distinction which

183. Cf. Elliot, supra note 182, at 1491.

184. Courts should only apply Chevron deference to legislative rules. Chevron U.S.A. Inc. v. National Resources Defense Council, Inc., 467 U.S. 837, 844 (1984); see also supra text accompanying notes $41-42$.

185. See Arthur E. Bonfield, Public Participation in Federal Rulemaking Relating to Public Property, Loans, Grants, Benefits, or Contracts, 118 U. PA. L. REV. 540, 541 (1970).

186. While it is true that courts are not infallible and are themselves "undemocratic" in nature, the principle of the courts as interpreters of the law is built into our constitutional structure. See Panel Discussion, supra note 39, at 371 (statement of Cass R. Sunstein). 
recognizes the fundamental role of public participation in the agency rulemaking process. Because imterpretive rules, as opposed to legislative rules, are not promulgated pursuant to notice-andcomment, they cannot bimd courts.

Second, Skidmore created a standard of deference for courts reviewing imterpretive rules. The decision counsels courts to evaluate the persuasiveness of agency positions and suggests factors for courts to consider when weighing the value of interpretive rules. In contrast, the Chevron decision offers a competing approach to judicial deference to agency action and has assumed a dominant role with respect to deference to agencies. Some judges' rejection and misapphication of Skidmore have endangered the distinctiveness of its deference principles and have displaced Skidmore with a Chevron analysis. Instead, courts should recognize the unique value of the deference principles of the two decisions. The doctrine of extreme deference mandated by Chevron applies to legislative rules; once a court determines that a statute is ambiguous, it must defer to any reasonable interpretation of the statute proposed by the agency. On the other hand, the cautious deference principle estabhished im Skidmore requires agencies to demonstrate the persuasiveness of their positions; the court engages in a searching inquiry into agency interpretations.

Skidmore remams the authoritative statement on the legal effect of imterpretive rules. But even more miportantly, the United States Supreme Court in EEOC v. Aramco confirmed that in an era of increasing judicial deference, courts must preserve the innperative distinction between legislation and interpretive rules by recognizing the continuing viabihty of the deference principles set forth in Skidmore v. Swift \& Co. 